\title{
KERUSAKAN STRUKTUR AKIBAT GETARAN LOKAL PADA KAPAL YANG JARANG DIPERHATIKAN: ANALISIS DAN SOLUSI (STUDI KASUS)
}

\author{
STRUCTURAL DAMAGE DUE TO LOCAL SHIP VIBRATION RESONANCE: A WIDELY \\ OVERLOOKED CASE, ANALYSIS AND SOLUTION
}

\author{
Asjhar Imron \\ Jurusan Teknik Perkapalan, FTK-ITS \\ Kampus ITS Keputih, Sukolilo, Surabaya 60111, Jawa Timur \\ E-mail:aimron@rad.net.id
}

Diterima tanggal: 6 Januari 2014, diterima setelah perbaikan: 21 Maret 2014, disetujui tanggal: 26 Maret 2014

\begin{abstract}
ABSTRAK
Pengabaian pengecekan potensi resonansi struktur lokal bisa berakibat serius pada kegagalan struktur. Studi ini menunjukkan kejadian tersebut, yang seharusnya bisa dihindari apabila pengecekan dilakukan pada tahap perancangan. Dalam studi ini identifikasi sederhana dilakukan untuk menentukan eksitasi paling dominan. Penentuan struktur lokal yg potensial beresonansi dilakukan dengan pengamatan visual dan dengan analisis menggunakan metode elemen hingga. Setelah resonansi dipastikan, perancangan ulang (redesign) dilakukan dengan memperhatikan kemudahan pelaksanaan di lapangan. Hasil redesign menunjukkan bahwa dengan menaikkan kekakuan konstruksi lokal maka terjadinya resonansi bisa digeser di luar daerah operasi kecepatan kapal untuk semua modes.
\end{abstract}

Kata kunci: getaran kapal, struktur lokal, resonansi, perancangan ulang.

\section{ABSTRACT}

The negligence of local structure resonance could have a serious consequence in the structural failure. This study shows a case in which the problem could have been avoided provided that enough attention and analysis is done during the design stage. The potentially resonant local structure is determined through visual inspection and analysis using finite element method. Once the resonance is determined, redesigned is done by paying special attention on the practical aspects during the construction. The redesign result shows that by increasing the stiffness of the local structure, the resonance frequency is shifted beyond the operating range of the ship speed for all modes concerned.

Keywords: ship vibration, local structure, resonance, redesign.

\section{PENDAHULUAN}

Praktek di lapangan sehubungan dengan pembangunan kapal baru di Indonesia belum memasukan pengecekan getaran sebagai bagian dari prosedur standar operasi (SOP), karena memang belum ada ketentuan klasifikasi yang rigid mengatur tentang hal tersebut (Ref).

Kelaziman yang dilakukan adalah mengambil hasil analisis dari getaran torsional sistem propulsi yang biasanya diberikan oleh supplier mesin induk untuk mendapatkan besarnya frekuensi naturalnya kemudian membandingkan apakah terjadi potensi resonansi. Sebagai contoh, metode Holzer (Den Hartog, 1956; Imron, 1985; Parsons, 1982), adalah metode yang cukup lama digunakan hampir secara universal untuk menentukan frekuensi natural (natural frequencies) dalam melakukan analisis getaran sistem propulsi.

Metode ini sudah sangat terkenal sejak jaman sebelum komputer elektronik karena algoritma ulangnya (recursive algorithm) yang relatif mudah diadopsi ketika kalkultor mulai muncul, utamanya dengan kalkulator yang bisa diprogram. Metode tersebut masih banyak dijumpai bahkan hingga kini karena hasilnya yang terbukti cukup akurat.

JURNAL KELAUTAN NASIONAL, Vol. 9, No.1, April 2014, Hal. 11-19 
Dengan popularitas dan kemudahan Metode Elemen Hingga, metode tersebut berangsur ditinggalkan.

Apabila hasil analisis tidak menunjukkan adanya potensi resonansi maka jarang dilakukan pengecekan terhadap potensi resonansi dengan struktur lokal. Kasus yang dipelajari dalam studi ini bermula dari kerusakan struktur yang cukup parah sehingga kapal ditangguhkan untuk berlayar, suatu pemborosan yang luar biasa mengingat kapal ini adalah dari jenis kapal patroli cepat.

Hal tersebut bisa dihindari kalau dari awal dihitung potensi resonansi dari beberapa struktur lokal. Personil lapangan dan perancang (designer) yang berpengalaman bisa memberikan rekomendasi awal tentang struktur lokal yang potensial beresonansi dengan sumber getaran (eksitasi) di kapal.

Dalam studi kasus ini terbukti bahwa terjadi resonansi yang kuat pada struktur geladak, baik geladak utama maupun geladak di kamar mesin dengan salah satu eksitasi yang paling dominan yaitu eksitasi baling-baling.

\section{BAHAN DAN METODE}

\subsection{Review Sumber dan Standar Getaran}

Ada banyak sekali eksitasi di kapal yang tentu saja tidak semuanya harus dilakukan analisis karena akan membutuhkan banyak waktu dan menjadi tidak efisien. Analis (designer) harus memilih eksitasi yang paling dominan berdasarkan engineering judgement-nya. Beberapa sumber getaran dominan di kapal antara lain gelombang laut, mesin utama penggerak kapal, baling-baling, dan mesin-mesin geladak.

Gelombang laut mempunyai frekuensi yang sangat rendah. Gelombang besarpun biasanya mempunyai frekuensi hanya sekitar $1 \mathrm{~Hz}$ (Vorus, 1990). Besarnya frekuensi natural untuk getaran struktur lokal biasanya berada pada kisaran $50 \mathrm{~Hz}$ ke atas.

Demikian pula dengan mesin induk yang lazimnya menggunakan mesin Diesel. Mesin Diesel putaran sedang yang lazim digunakan berkisar antara 500 s/d 1000 RPM atau sekitar $8,3 \mathrm{~Hz} \mathrm{~s} / \mathrm{d} 16,6 \mathrm{~Hz}$, masih jauh di bawah potensi resonansi dengan struktur lokal. Maka baling-baling adalah satusatunya kandidat eksitasi getaran yang dominan untuk getaran struktur lokal yang dianalisis ini, yang akan dibahas lebih detil pada bab selanjutnya.

Sedikit review tentang Standar Getaran yang dipakai di lapangan. Meskipun komunitas ilmiah dalam bidang Teknik Perkapalan (Naval Architecture) menghasilkan banyak kriteria untuk getaran, lihat misalnya (Savreux, 2007), namun Standar yang lazim digunakan di lapangan adalah ISO Guide 6954 tahun 1984 (International Organization for Standardization, 1984) atau versi dari ISO Guide tersebut yang diadopsi oleh ABS Guide tahun 2006 (American Bureau of Shipping 2004).

Untuk waktu yang cukup lama, guide yang banyak digunakan adalah ISO Guide yang dipublikasikan tahun 1973 di Marine Technology (Reed, 1973). Guide ini mengatur tentang lama exposure seseorang terhadap getaran dengan frekuensi tertentu sebelum orang tersebut mulai merasakan tanda-tanda kelelahan (fatique). Besaran yang digunakan adalah amplitudo displasemen, yang berbeda dari yang sekarang lazim digunakan yaitu amplitudo kecepatan. Menurut Gordon (Gordon, 1993) hal ini karena letak kecepatan yang berada diantara displasemen dan percepatan. Sebenarnya tidak ada bedanya besaran manapun yang digunakan sehingga ISO maupun ABS mengadopsi ketiga besaran tersebut dalam satu Grafik.

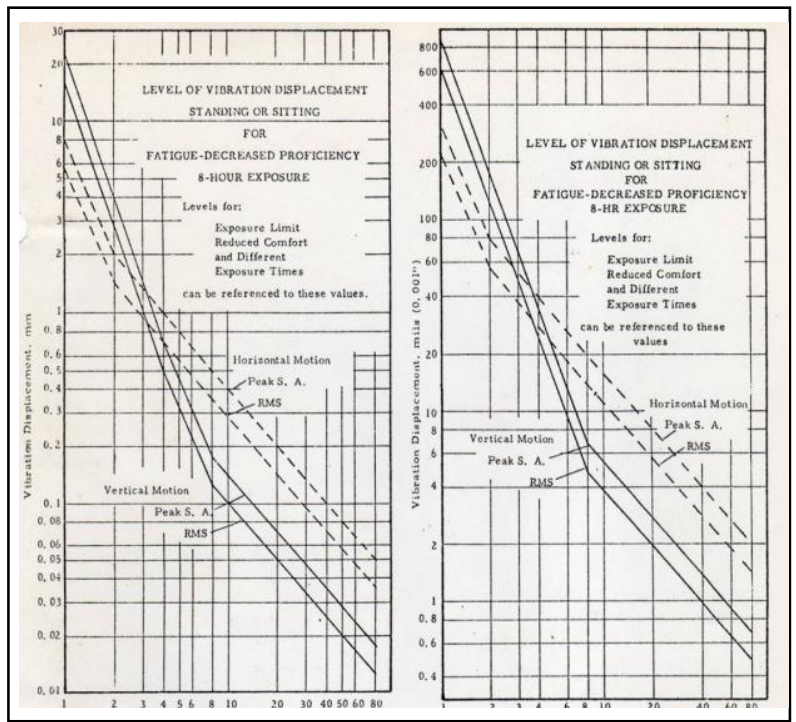

Gambar 1. ISO Guide 1972 tentang getaran Figure 1.ISO Guide 1972 about vibration Sumber : Marine Technology, 1973 


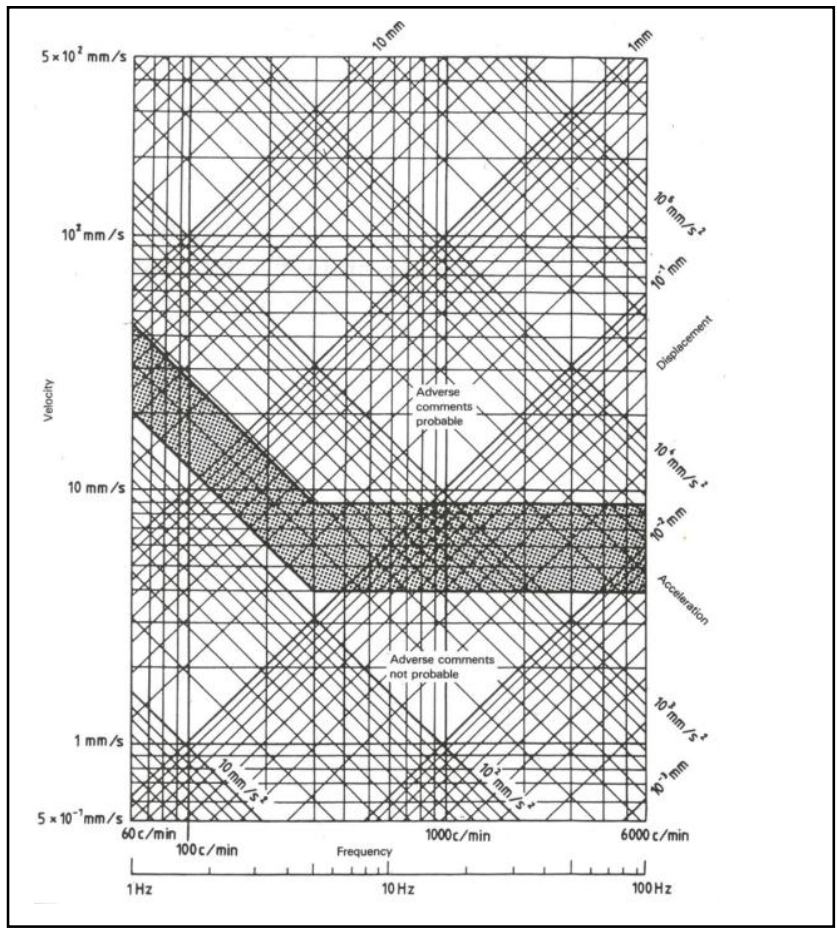

Gambar 2. ISO Guide 6954 tentang getaran Figure 2. ISO Guide 6954 about vibration Sumber : ISO Guidelines 6954198

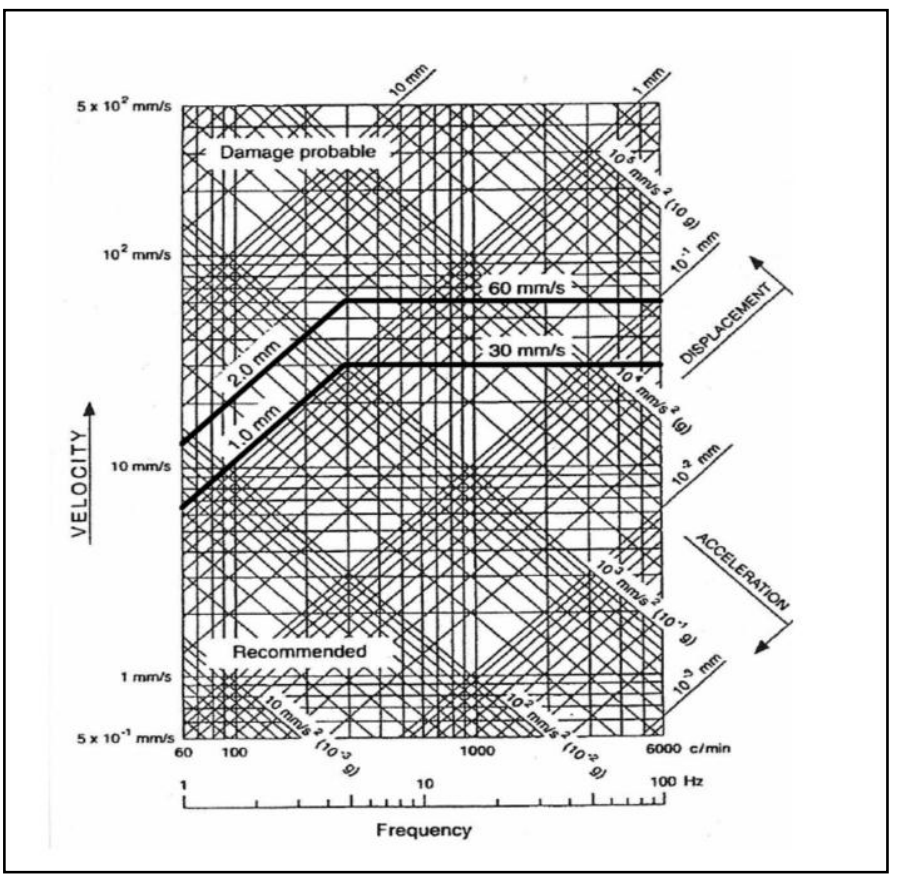

Gambar 3. ABS Guide 2006 tentang getaran Figure 3. ABS Guide 2006 about vibration Sumber: ABS Guide 2006

Hal ini karena karena asumsi fungsi harmonik yang digunakan, yaitu apabila Displasemen $($ displacement $)=\mathrm{X}$, maka Kecepatan $($ velocity $)=\omega$ $\mathrm{X}$, dan Percepatan (acceleration $)=\omega 2 \mathrm{X}$.
Ketiga spec getaran tersebut bisa dilihat pada Gambar 1, 2 dan 3. Gambar 3 adalah salah satu contoh kriteria yang diusulkan oleh lembaga non ISO, dalam hal ini ABS (American Bureau of 
Shipping, 2006) sebagai salah satu klasifikasi yang banyak membuat kriteria tentang getaran.

Kriteria ABS didasarkan pada kriteria ISO 1984 dengan beberapa penambahan. Dari gambar terlihat bahwa di bawah frekuensi $5 \mathrm{~Hz}$, amplitudo yang digunakan adalah displasemen, sedangkan di atas $5 \mathrm{~Hz}$ amplitudo yang digunakan adalah kecepatan. Kecepatan di atas $60 \mathrm{~mm} / \mathrm{s}$ adalah batas paling atas.

Perlu disebutkan bahwa ISO melakukan revisi terhadap Guideline 6954 (1984) dengan Guideline 6954 (International Organization for Standardization, 2000) yang memperhitungkan RMS dengan memberikan bobot keseluruhan frequency range dari $1 \mathrm{~s} / \mathrm{d} 80 \mathrm{~Hz}$. Guideline ISO 6954 ini membagi kriteria menjadi tiga zona, seperti disederhanakan dalam Tabel 1.

Masih banyak beberapa klasifikasi yang memberikan kriteria dan guidelines terkait masalah getaran di kapal, diantaranya dua klasifikasi besar GL (Germanischer Loyd, 2001) dan LR (Lloyd's Register, 2006) sekedar sebagai contoh.

Dari semua Guidance tersebut ada satu kecenderungan yang hampir sama yaitu semakin ketatnya kriteria untuk getaran kapal dari waktu ke waktu.

Gambar 4 adalah tren yang direkam oleh Bureau Veritas (Savreux, 2007) selama lebih dari dua dekade. Dari grafik bisa dilihat bahwa ada pengetatan hampir 50\% terhadap kriteria yang bisa diterima pada tahun 80-an dibanding dengan kapalkapal yang saat ini sedang dibangun. Pengetatan ini sejalan dengan tuntutan kenyamanan masyarakat, yang biasanya berkorelasi dengan tingkat kesejahteraan sosial. Dengan demikian masalah getaran pada kapal tidak lagi hanya sekedar topik sampingan tapi harus mendapat porsi yang cukup dalam proses perancangan.

Tabel 1. Standar getaran dengan memperhatikan RMS seluruh frekuensi Table 1. Noting RMS vibration standard with all frequency

\begin{tabular}{|c|c|c|c|c|c|c|}
\hline & \multicolumn{6}{|c|}{ Area Classification } \\
\hline & \multicolumn{2}{|c|}{$A$} & \multicolumn{2}{|c|}{$B$} & \multicolumn{2}{|c|}{$C$} \\
\hline & $\mathrm{mm} / \mathrm{s}^{2}$ & $\mathrm{~mm} / \mathrm{s}$ & $\mathrm{mm} / \mathrm{s}^{2}$ & $\mathrm{~mm} / \mathrm{s}$ & $\mathrm{mm} / \mathrm{s}^{2}$ & $\mathrm{~mm} / \mathrm{s}$ \\
\hline $\begin{array}{c}\text { Values above which adverse } \\
\text { comments are probable }\end{array}$ & 143 & 4 & 214 & 6 & 286 & 8 \\
\hline $\begin{array}{l}\text { Values below which adverse } \\
\text { comments are not probable }\end{array}$ & 71,5 & 2 & 107 & 3 & 143 & 4 \\
\hline \multicolumn{7}{|c|}{$\begin{array}{l}\text { Sumber: ISO Guideline } 69542000 \\
\text { Note: The zone between upper and lower values reflects the shipboard vibration environment experienced and accepted. } \\
\text { Area Classification } \quad \text { A: } \quad \text { Passenger Accomodations } \\
\qquad: \quad \text { Crew Accomodations } \\
\text { C: } \quad \text { Work spaces }\end{array}$} \\
\hline
\end{tabular}

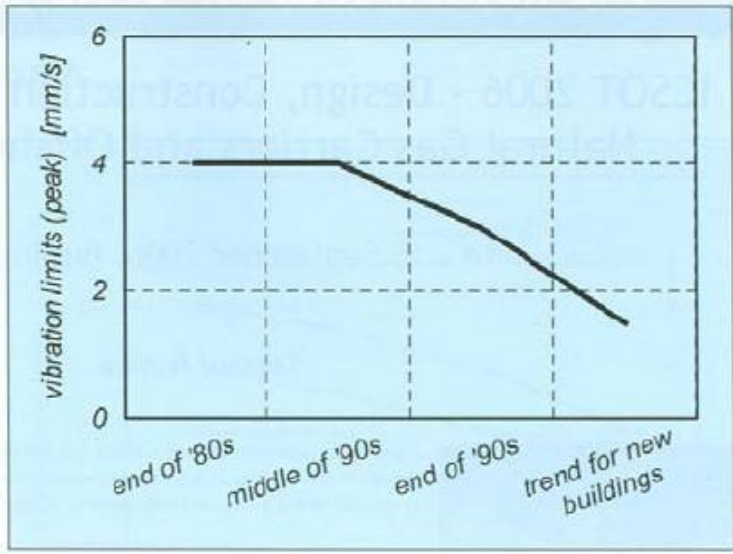

Gambar 4. Trend batas getaran maksimum di ruang akomodasi

Figure 4. Trend limit the maximum vibration in accommodation spaces Sumber: Savreux, 2007 


\subsection{Eksitasi Paling Dominan}

Data empiris menunjukkan bahwa sekitar $80 \%$ penyebab getaran pada kapal adalah balingbalingnya, meskipun mungkin ini membutuhkan penjelasan lebih lanjut bagi yang terbiasa dengan analisis Power Plant di darat, karena munculnya blade rate frequency yang tidak dikenal dalam getaran di Power Plant (Vorus, 2010)

Ketika kapal sudah dibangun, cara terbaik untuk memastikan apakah suatu getaran pada struktur kapal disebabkan oleh baling-balingnya adalah dengan melakukan pengukuran getaran yang terjadi pada struktur tersebut.

Dua kriteria emperis berikut lazim digunakan (Vorus, 2010):

1. Apabila besarnya frekuensi getaran yang diukur sama dengan besar RPM poros dikalikan jumlah daun baling-baling, dan frekuensi tersebut berubah dengan berubahnya RPM poros tersebut, maka hampir bisa dipastikan bahwa baling-baling adalah sumber getaran utamanya (exciting force).

2. Sebaliknya, apabila frekuensi tersebut (dikenal dengan sebutan blade rate frequency) atau kelipatannya sama sekali tidak terdeteksi dalam pengukuran maka hampir bisa dipastikan bahwa baling-baling bukan sebagai penyebabnya.
Persoalannya, ketika masih pada tahap perancangan bagaimana pengukuran itu dilakukan? Dengan bantuan pemodelan menggunakan metode elemen hingga untuk beberapa struktur lokal yang "dicurigai" kemungkinan terjadinya resonansi, hal tersebut bisa dilakukan dengan relatif mudah seperti yang ditunjukkan dalam studi ini.

Dalam kasus ini, kapal sudah jadi dan getaran diketahui cukup besar pada beberapa lokasi di geladak di atas ruang mesin dan di dasar ganda pada ruang mesin, sehingga pengukuran dilakukan pada lokasi-lokasi tersebut. Untuk non-cavitating propeller yaitu baling-baling yang digunakan di sini getaran yang besar tersebut kemungkinan adalah getaran resonansi.

Pengukuran amplitudo dan frekuensi dilakukan dengan memvariasi besarnya RPM dan mengukur amplitudo dan frekuensi pada setiap RPM. Posisi pengukuran pada 3 lokasi sampling $(7,8,9)$ bisa dilihat pada Gambar 5.

Hasil pengukuran (Tabel 2) membuktikan dugaan awal, bahwa:

- Sumber getaran adalah baling-baling

- Terjadi resonansi dengan struktur lokal yang dalam hal ini adalah geladak utama

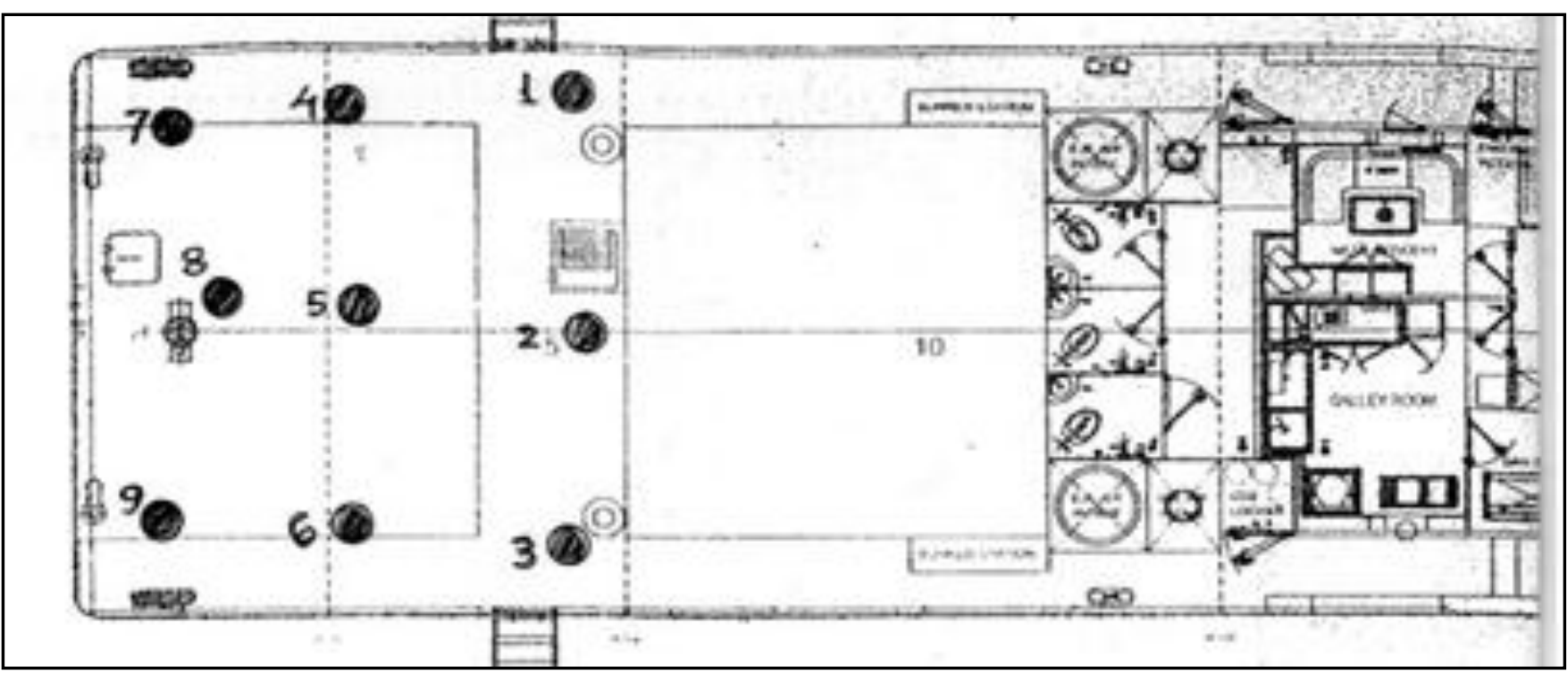

Gambar 5. Posisi pengukuran getaran di geladak utama(dari pengukuran lapangan) Figure 5. Position measurement of vibration in the main deck (from field measurements) Sumber : Hasil analisis 
Tabel 2. Hasil pengukuran getaran di geladak

Table 2. The results of vibration measurements in the deck

\begin{tabular}{|c|c|c|c|c|c|c|c|c|c|c|c|c|c|}
\hline \multirow{3}{*}{$\begin{array}{l}\text { MEAS } \\
\text { POINT }\end{array}$} & \multirow{3}{*}{ Direct } & \multicolumn{12}{|c|}{ Velocity dan Frekuensi Getaran } \\
\hline & & \multicolumn{2}{|c|}{$0 \% \mathrm{RPM}$} & \multicolumn{2}{|c|}{$25 \%$ RPM } & \multicolumn{2}{|c|}{$50 \%$ RPM } & \multicolumn{2}{|c|}{$80 \%$ RPM } & \multicolumn{2}{|c|}{$90 \%$ RPM } & \multicolumn{2}{|c|}{$100 \%$ RPM } \\
\hline & & Vel & Frek & Vel & Frek & Vel & Frek & Vel & Frek & Vel & Frek & Vel & Frek \\
\hline \multirow[t]{3}{*}{7} & $\mathrm{~L}$ & 0 & 0 & 0,1343 & 47 & 0,3725 & 31 & 4,706 & 45 & 1,149 & 48 & 6,866 & 52 \\
\hline & $\mathrm{V}$ & 0 & 0 & 0,1892 & 47 & 0,8209 & 31 & 6,970 & 45 & 7,066 & 48 & 6,006 & 52 \\
\hline & $\mathrm{T}$ & 0 & 0 & 0,2228 & 19 & 0,2491 & 31 & 3,983 & 45 & 2,271 & 48 & 6,592 & 52 \\
\hline \multirow[t]{3}{*}{8} & $\mathrm{~L}$ & 0 & 0 & 0,1373 & 49 & 0,6134 & 31 & 6,183 & 45 & 9,799 & 48 & 1,659 & 52 \\
\hline & $\mathrm{V}$ & 0 & 0 & 0,1709 & 47 & 1,4890 & 63 & 7,748 & 45 & 3,516 & 48 & 16,81 & 52 \\
\hline & $\mathrm{T}$ & 0 & 0 & 0,1221 & 34 & 0,7965 & 31 & 2,216 & 45 & 3,763 & 48 & 9,127 & 52 \\
\hline \multirow[t]{3}{*}{9} & $\mathrm{~L}$ & 0 & 0 & 0,1706 & 49 & 0,4333 & 31 & 4,843 & 45 & 9,575 & 48 & 7,908 & 52 \\
\hline & $\mathrm{V}$ & 0 & 0 & 0,1495 & 34 & 0,7267 & 31 & 5,396 & 45 & 1,027 & 48 & 4,916 & 52 \\
\hline & $\mathrm{T}$ & 0 & 0 & 0,1739 & 47 & 0,3998 & 63 & 4,373 & 45 & 4,285 & 48 & 4,056 & 52 \\
\hline
\end{tabular}

$*$ Vel $=$ velocity $(\mathrm{mm} / \mathrm{sec}) *$ Frek $=$ Frekuensi $(\mathrm{Hz})$

Sumber: Hasil pengukuran langsung

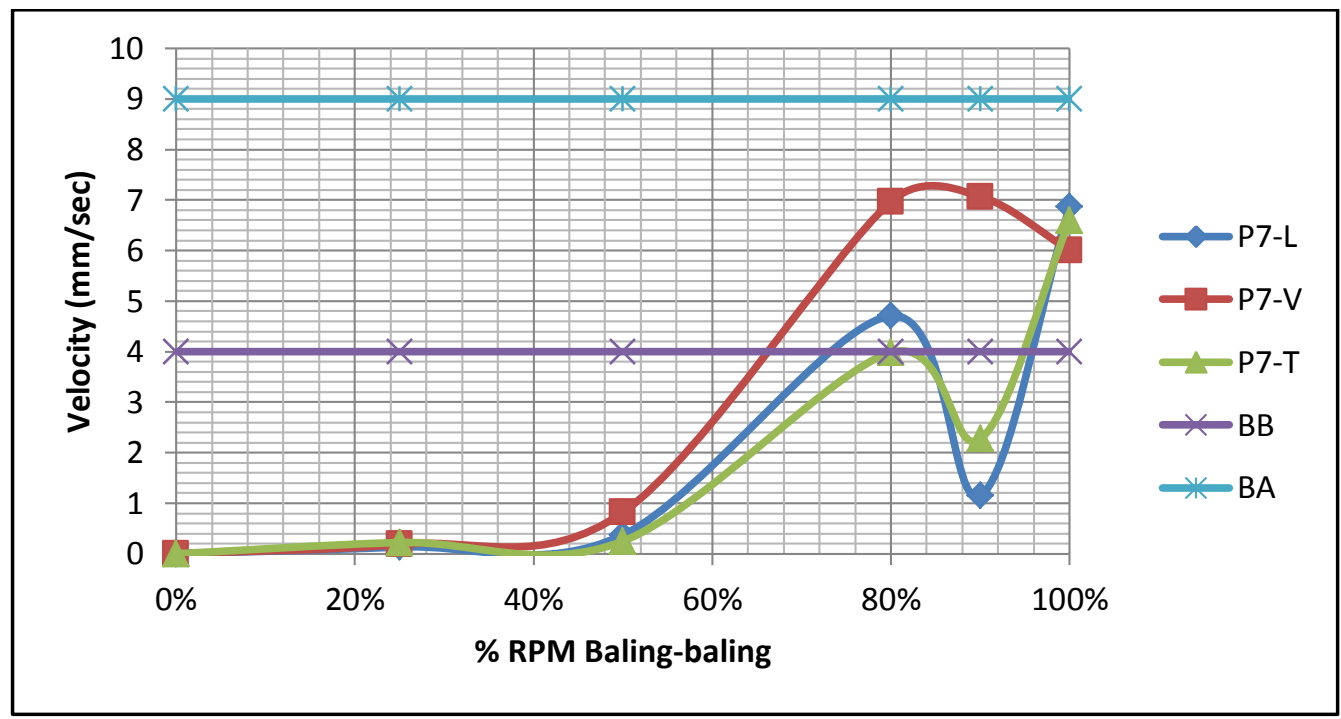

Gambar 6. Hasil pengukuran getaran posisi 7 di geladak utama

Figure 6. The results of vibration measurement position 7 in the main deck

Sumber: Hasil pengukuran

\section{HASIL DAN PEMBAHASAN}

Karena standar getaran yang lazim digunakan di Indonesia adalah ISO 6954 tahun 1984, maka standar itu pulalah yang digunakan dalam studi ini, hal ini hanya untuk alasan kelaziman saja karena standar lain bisa dengan mudah digunakan. Sebagai tinjauan lanjut, disarankan ada studi tambahan untuk membandingkan beberapa standar yang diaplikasikan pada kasus yang sama untuk melihat standar mana yang mempunyai persyaratan paling ketat.
Untuk menentukan struktur lokal yang paling rentan terhadap kemungkinan terjadinya resonansi, dilakukan dengan membandingkan besarnya frekuensi natural struktur lokal yang dicurigai dengan besarnya frekuensi eksitasi baling-baling yang menyebabkan getaran paling besar pada struktur yang sama. Apabila besaran kedua frekuensi itu berdekatan maka bisa dipastikan bahwa resonansi telah terjadi.

Besar frekuensi natural dihitung dengan memodelkan struktur lokal menggunakan metode elemen hingga, sedangkan besarnya variasi getaran 
yang terjadi sebagai fungsi frekuensi eksitasi diukur langsung dari lapangan pada beberapa sampling points (Gambar 6, contoh pada posisi 7).

Dengan mengkombinasikan analisis dan engineering judgment tidak terlalu sulit untuk menentukan struktur lokal yang potensial terjadi resonansi, apalagi kalau bisa dilihat langsung pada kapal yang sudah ada seperti pada studi kasus ini. Dalam hal kapal masih dalam perancangan, analyst yang berpengalaman bisa melakukan trial \& error berdasarkan data-data empiris.

Dari pengamatan visual di lapangan terlihat jelas bahwa kandidat struktur lokal yang paling rentan adalah Geladak Utama dan Geladak Kamar Mesin. Dalam studi ini hanya dibahas Geladak Utama saja karena pada dasarnya semua prosedur dan perhitungan tidak berbeda.

Pada studi kasus ini kapal mempunyai balingbaling dengan 4 daun dan RPM baling-baling maksimum 824 , atau $\frac{824}{60} \times 4=55 \mathrm{~Hz}$ (blade rate frequency). Besarnya frekuensi hasil pengukuran pada posisi geladak utama di atas kamar mesin yang diidentifikasi mempunyai getaran paling besar adalah sekitar $52 \mathrm{~Hz}$. Dengan demikian terlihat dengan jelas bahwa baling-baling adalah penyebab utama getaran yang besar pada geladak utama di atas kamar mesin tersebut (selanjutnya disebut geladak utama). Posisi pengukuran getaran pada geladak utama ditunjukkan oleh Gambar 5di atas, sedangkan hasil pengukuran pada Posisi 7, 8, 9 (getaran terjelek) diberikan pada Tabel 2 di atas.

Hasil pengukuran kecepatan ini memverifikasi kecurigaan sebelumnya bahwa getaran pada posisi tersebut memang sudah di atas kriteria yang diijinkan. Pengukuran dilakukan untuk tiga arah getaran yaitu velocity ke arah longitudinal (L), vertical $(\mathrm{V})$, dan transversal $(\mathrm{T})$, serta grafik batas bawah dan atas, yang menunjukkan range atau jangkauan getaran yang diizinkan pada saat kapal beroperasi.

Sebagai ilustrasi untuk posisi 7, hasil dalam Tabel 2 di atas ditampilkan kembali dalam bentuk grafik dengan memasukkan kriteria dari ISO $(\mathrm{BB}=$ Batas Bawah, dan BA = Batas Atas). Dari Tabel 2 bisa dilihat bahwa pada posisi 8 besarnya getaran hampir 1,5 kali dibanding pada posisi 7 sehingga dipastikan batas atas kriteria getaran jauh terlampaui.

Dengan demikian dari hasil pengukuran ini bisa disimpulkan tanpa ada keraguan bahwa:

- Baling-baling adalah penyebab utama terjadinya getaran

- Struktur lokal dalam hal ini geladak utama terlalu lemah sehingga beresonansi dengan baling-baling pada kecepatan penuh, yaitu cruising speed yang dalam kasus ini justru kecepatan tersebut yang paling dibutuhkan dalam operasional kapal.

\section{Pemodelan Elemen Hingga}

Pemodelan ini digunakan untuk menentukan besarnya frekuensi natural pada Geladak Utama sebagai salah satu struktur lokal yang diidentifikasi mempunyai potensi resonansi dengan eksitasi baling-baling (pemodelan dan analisis juga dilakukan pada geladak kamar mesin seperti disebutkan sebelumnya, namun tidak disampaikan dalam studi ini).

Dengan Metode Elemen Hingga dan kemudahan grafik komputer, pemodelan bisa sekaligus dilakukan untuk kondisi existing dan kondisi redesign sekaligus. Diputuskan untuk tidak melakukan perubahan konfigurasi struktur karena akan sangat sulit dilakukan mengingat kondisi kapal yang sudah jadi.

Tabel 3. Kondisi batas pada geladak utama

Table 3. The boundary conditions on the main deck

\begin{tabular}{|c|c|c|c|c|c|c|c|c|}
\hline \multirow{2}{*}{ No. } & \multirow{2}{*}{ Lokasi } & \multirow{2}{*}{$\begin{array}{c}\text { Simbol } \\
\text { Garis Warna }\end{array}$} & \multicolumn{3}{|c|}{ Translasi } & \multicolumn{3}{|c|}{ Rotasi } \\
\hline & & & $\mathrm{x}$ & $\mathrm{y}$ & $\mathrm{Z}$ & $\mathrm{x}$ & $\mathrm{y}$ & $\mathrm{Z}$ \\
\hline 1. & $\begin{array}{l}\text { Setiap sisi area main deck yang } \\
\text { dimodelkan }\end{array}$ & Merah & fixed & fixed & fixed & fixed & fixed & fixed \\
\hline 2. & Daerah wall & Biru & fixed & fixed & fixed & free & free & free \\
\hline 3. & Daerah pilar & Hijau & fixed & fixed & fixed & free & free & free \\
\hline
\end{tabular}


Untuk alasan efisiensi dan ekonomis, redesign hanya dilakukan dengan merubah scantling (ukuran) dari profil-profil tertentu saja. Kondisi batas untuk kedua pemodelan (sebelum dan sesudah redesign) juga tidak mengalami perubahan, lihat Tabel 3.

Pemodelan tersebut bisa dilihat di Gambar 7. Hasil sepuluh frekuensi natural pertama diberikan di Tabel 4. Karena frekuensi natural ke 10 besarnya hampir dua kali dari frekuensi natural pertama di mode 1, maka mode ke 11 dst tidak relevan lagi karena jauh di atas operating range dari kapal

Dari hasil analisis terlihat bahwa frekuensi natural geladak utama untuk mode pertama $(=54,86 \mathrm{~Hz})$ memiliki nilai yang mendekati blade rate frequency dari baling-baling yaitu sebesar $55 \mathrm{~Hz}$ sebagaimana telah dihitung di atas. Dengan demikian telah terjadi resonansi antara blade rate frequency dari baling-baling dengan frekuensi natural struktur lokal yaitu geladak utama (main deck) bagian buritan kapal. Hal ini sesuai dengan hasil pengukuran dimana terjadi getaran berlebihan pada geladak utama buritan kapal sebagai akibat dari terjadinya resonansi ini.

\section{KESIMPULAN DAN SARAN}

Pada tahap perancangan, ada beberapa opsi yang bisa dipilih:

1. Merubah besarnya RPM baling-baling

2. Merubah jumlah daun baling-baling

3. Memperkecil amplitudo eskitasi gaya dorong baling-baling (thrust)

4. Merubah frekuensi natural struktur yang beresonansi.

Opsi 1 s/d 3 bisa menjadi pilihan pada tahap perancangan, namun ketika kapal sudah selesai dibangun maka opsi tersebut bukan pilihan yang tepat karena pertimbangan biaya dan waktu. Solusi yang dipilih dalam studi kasus ini adalah merubah frekuensi natural dari geladak utama dengan membuatnya lebih tegar (stiff), yaitu dengan memberikan penguatan tambahan atau memperbesar modulus penampang dari konstruksi yang sudah ada.

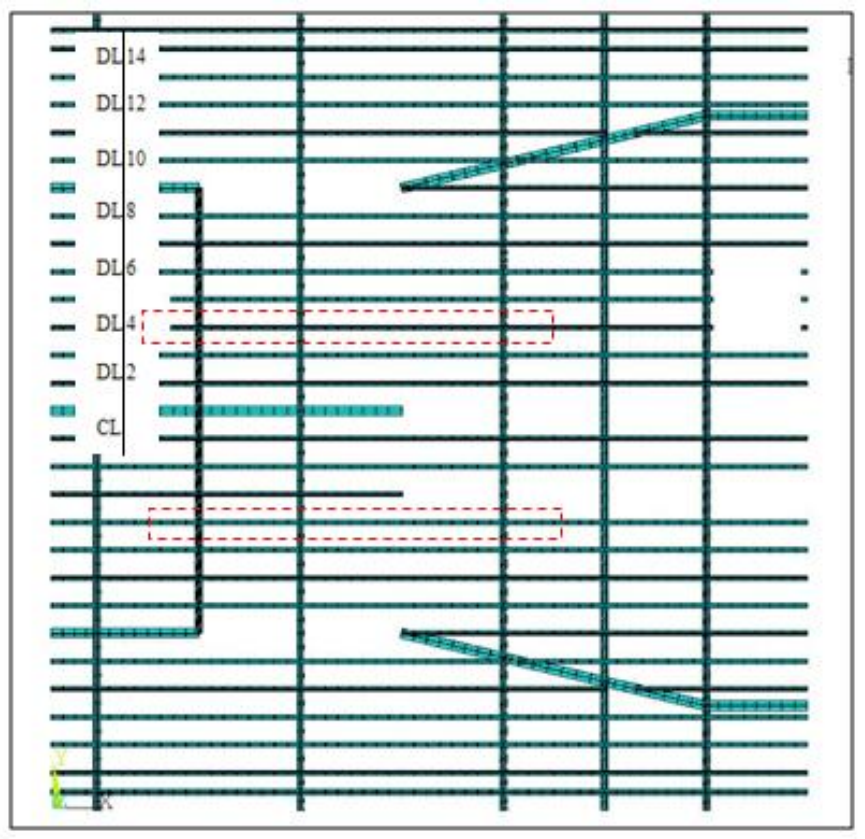

Gambar 7. Hasil redesign (warna merah/garis strip) Figure 7. Results of redesign (red/stripe/strip) Sumber : hasil analisis

Dengan cara ini maka hanya diperlukan perubahan struktur seminimal dan sesederhana mungkin sehingga mudah dilakukan perubahan di lapangan. Penguatan struktur geladak utama dilakukan seperti pada Gambar 7 dan 8. Besarnya frekuensi natural sebelum dan sesudah redesign diberikan oleh Tabel 4 berikut.

Tabel 4. Frekuensi natural sebelum dan sesudah redesign

Table 4. Natural frequency before and after redesign

\begin{tabular}{ccc}
\hline \multirow{2}{*}{ Mode } & \multicolumn{2}{c}{ Frekuensi Natural } \\
\cline { 2 - 3 } & Sebelum & Sesudah \\
\hline 1 & 54,860 & 72,619 \\
\hline 2 & 55,726 & 73,225 \\
\hline 3 & 55,836 & 85,992 \\
\hline 4 & 56,569 & 88,076 \\
\hline 5 & 71,387 & 95,419 \\
\hline 6 & 84,398 & 98,008 \\
\hline 7 & 92,637 & 104,02 \\
\hline 8 & 98,553 & 121,39 \\
\hline
\end{tabular}

Sumber: Hasil analisis 


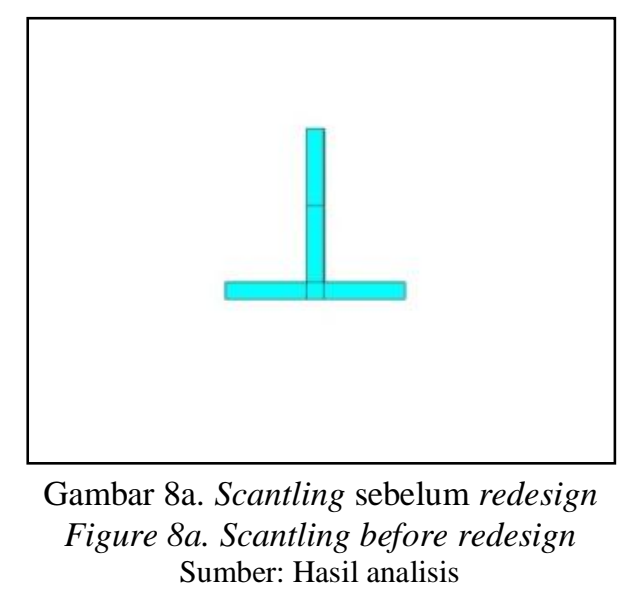

Dari Tabel 4 dapat dilihat bahwa frekuensi natural geladak utama yang telah didesain ulang pada mode 1 menjadi $72.619 \mathrm{~Hz}$ (sebelumnya $54,86 \mathrm{~Hz}$ ). Frekuensi natural ini berada jauh diluar blade rate frequency $(55 \mathrm{~Hz})$ sehingga tidak lagi terjadi resonansi pada operating range. Mode 2 dan seterusnya tidak mempunyai konsekuensi apapun karena sudah jauh berada di luar operating range dari kapal.

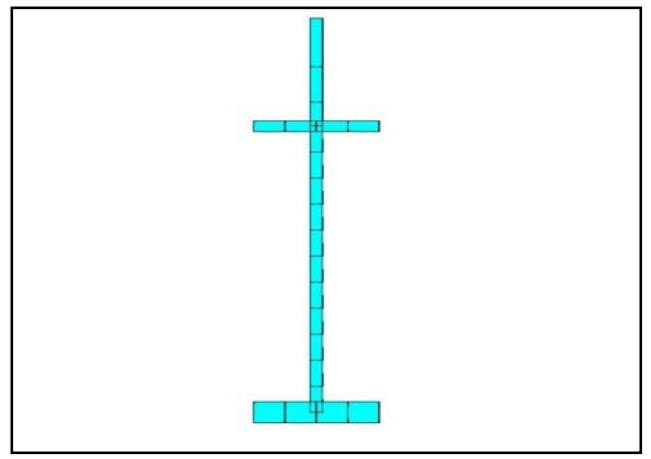

Gambar 8b. Scantling sesudah redesign Figure 8b.Scantling after redesign Sumber: Hasil analisis

Kasus ini menunjukkan bahwa pada kapal-kapal cepat dan kapal-kapal yang mempunyai mesin besar, maka pengecekan potensi resonansi harus dilakukan pada tahap perancangan untuk beberapa konstruksi lokal. Dalam kondisi dimana redesign terpaksa harus dilakukan, pemilihan struktur yang di-redesign menjadi krusial agar menghemat waktu dan biaya.

\section{DAFTAR PUSTAKA}

American Bureau of Shipping. (2006). Guidance Notes on Ship Vibration. USA.
Den Hartog, J. P. (1956). Mechanical Vibration, Mc Graw Hill Book. New York.

Germanischer Lloyd. (2001). GL Technology: Ship Vibration. Hamburg, Germany.

Gordon, C.G. (1993). Generic Vibration Criteria for Vibration-Sensitive Equipment. Colin Gordon \& Associates. San Mateo, CA.

Imron, A. (1985). Analisis Geteran Longitudinal Sistem Propulsi Kapal. Pusat Penelitian ITS, Surabaya.

International Organization for Standardization. (1984). ISO Guidelines 6954 1984. Switzerland.

International Organization for Standardization. (2000). ISO Guidelines 6954 2000. Switzerland.

Lloyd's Register. (2006). Ship Vibration and Noise: Guidance Notes. London, UK.

Parsons, M. G. (1982). Vibration of Ship Propulsion System. Dept. Naval Architecture \& Marine Engineering. the University of Michigan, USA.

Reed, F. E. (1973) Acceptable levels of vibration on ships. Marine Technology, Society of Naval Architects and Marine Engineers. New Jersey.

Savreux, K, Crouzet, S., and Andreau, C. (2007). Overview of comfort criteria for vibration assessment proposed by ISO 6954 and different classification societies. Ship Noise and Vibration Conference. London, UK.

Vorus, W.S. (1990). Ship Vibration. Dept. Naval Architecture \& Marine Engineering. the University of Michigan. USA.

Vorus, W.S. (2010). Vibration. The Principles of Naval Architecture Series. Society of Naval Architects and Marine Engineers. New Jersey.

Yucel, A., \& Arpaci, A. (2013). Free and forced vibration analyses of ship structures using the finite element method. Journal of Marine Science and Technology, 18(3), 324-338. 